\title{
SOIL ORGANIC MATTER FRACTIONS IN PRESERVED AND DISTURBED WETLANDS OF THE CERRADO BIOME
}

\author{
Ricardo Fernandes de Sousa(1), Eliana Paula Fernandes Brasil(2), Cícero Célio de \\ Figueiredo(3)* and Wilson Mozena Leandro(2) $^{(2)}$
}

(1) Instituto Federal de Educação, Ciência e Tecnologia de Goiás, Campus Goiânia, Goiânia, Goiás, Brasil.
(2) Universidade Federal de Goiás, Escola de Agronomia, Campus Samambaia, Goiânia, Goiás, Brasil.
(3) Universidade de Brasília, Faculdade de Agronomia e Medicina Veterinária, Brasília, Distrito Federal, Brasil.
* Corresponding author.
E-mail: cicerocf@unb.br

\begin{abstract}
Veredas are humid tropical ecosystems, generally associated to hydromorphic soils and a shallow water table. The soils of these ecosystems are affected by the use of the areas around these veredas. The objective of this study was to determine soil organic matter (SOM) fractions in veredas adjacent to preserved (native savanna) and disturbed environments (agricultural areas and pastures) in the Cerrado biome. Soil samples were collected from the 0-10 and $10-20 \mathrm{~cm}$ layers along reference lines drawn along the relief following the upper, middle and lower positions of one of the slopes, in the direction of the draining line of the vereda. The soil analysis determined: total soil $\mathrm{OC}$, total nitrogen and $\mathrm{C}: \mathrm{N}$ ratio; $\mathrm{C}$ and $\mathrm{N}$ contents and C:N ratio in particulate and mineral-associated fractions (of SOM); fulvic acids, humic acids and humin fractions and ratio between humic and fulvic acids. The agricultural use around the veredas induced changes in the SOM fractions, more pronounced in the lower part of the slope. In the soil surface of this part, the OC levels in the humic substances and the particulate fraction of SOM, as well as total soil OC were reduced in the vereda next to crop fields.
\end{abstract}

Keywords: hydromorphic soils, land use, particulate fraction, humic substances, organic carbon.
RESUMO: FRAÇÕES DA MATÉRIA ORGÂNICA DO SOLO EM VEREDAS CONSERVADAS E ANTROPIZADAS NO BIOMA CERRADO

As veredas são ecossistemas tropicais úmidos, geralmente associados a solos hidromórficos e afloramento do lençol freático. Os solos desses ecossistemas sofrem alterações conforme o uso 


\begin{abstract}
das áreas do entorno dessas veredas. Este trabalho teve como objetivo determinar as frações da matéria orgânica do solo (MOS) em áreas úmidas (veredas) adjacentes a ambientes conservados e antropizados (em áreas agrícolas e pastagens), no bioma Cerrado. Amostras de solo foram coletadas nas profundidades de 0-10 e 10-20 cm, ao longo de linhas de referência dispostas, segundo sua posição no relevo, nas posições superior, média e inferior de uma das vertentes, acompanhando o sentido da linha de drenagem da vereda. Foram determinados o $C$ orgânico total e $N$ total do solo, bem como a relação $C: N$, teores de $C, N$ e relações $C: N$ das frações particulada e associada a minerais (da MOS), além do C das frações ácidos fúlvicos, ácidos húmicos e humina e relação entre ácidos húmicos e fúlvicos. $O$ uso agropecuário da terra no entorno das veredas promoveu diminuição dos teores de $C$ das frações da MOS, de forma mais pronunciada na porção inferior da vertente. Nessa porção, em superfície, os níveis de C orgânico contidos nas substâncias húmicas e na fração particulada da MOS, do mesmo modo que o C orgânico total do solo, foram reduzidos na vereda vizinha a áreas de cultivo.
\end{abstract}

Palavras-chave: solos hidromórficos, uso da terra, fração particulada, substâncias húmicas, carbono orgânico.

\section{INTRODUCTION}

The Cerrado biome covers an area of around 2 million $\mathrm{km}^{2}$, encompassing a vast section of South America, and approximately $22 \%$ of the Brazilian territory. In the past four or five decades, this entire region underwent significant changes in terms of vegetation cover and land use, with consequent impacts on the environment and natural resources. Therefore, in many areas in the surroundings of the veredas and water springs, or on the banks of watercourses, the original (native) vegetation has been suppressed and replaced mostly by pastures and agricultural crops.

Veredas are humid tropical ecosystems, generally associated to hydromorphic soils and a shallow water table, occurring frequently near water springs or gallery forests along watercourses in the Cerrado region (Ribeiro and Walter, 1998). Therefore, they play a key role in the balance of the biogeochemical processes that regulate the availability and quality of water resources. However, following the occupation of the Cerrado, many areas located near the veredas were converted to pasture or agricultural crops, often disregarding the regulations of the current Brazilian legislation (Forest Code), which establishes a radius of $50 \mathrm{~m}$ around water resources as permanent preservation areas (PPA) for the protection of the water bodies and soil.

Land use or management practices may change the soil organic matter (SOM) content and quality, affecting the stocks of SOM and causing changes in the levels of major SOM elements, such as $\mathrm{C}$ and/or N (Liu et al., 2006; Carvalho et al., 2010). The replacement of natural vegetation cover by agricultural crops and pastures, associated to the use of inadequate management practices, may cause a significant reduction in SOM stocks, leading to considerable losses of soil $\mathrm{C}$ and N (Guo and
Gifford, 2002; Machado, 2005; Batlle-Bayer et al., 2010; Wendling et al., 2011).

In humid areas and veredas, environmental impacts and changes in ecological properties and functions can be caused not only by the direct use of these areas, but also by the use of the surrounding areas for agricultural purposes (Burbridge, 1994; Houlahan et al., 2006). Several studies demonstrated that organic matter dynamics in wet areas (under hydromorphic conditions), as well as other soil properties, can be influenced by environmental changes caused by land use and management (Ebeling et al., 2004; Santos et al., 2004; Sigua et al., 2006; Sousa et al., 2011).

Soil organic matter is recognized as one of the most important factors in the assessment of soil quality and conditioning, being constituted by several fractions (Gregorich et al., 1997; Nortcliff, 2002; Bastida et al., 2008). Although the determination of total organic carbon (TOC) content alone cannot express the changes resulting from soil use in certain situations, it is often used to quantify SOM levels and changes (Figueiredo et al., 2010). In these cases, the great diversity of SOM fractions or the relative distribution of $\mathrm{C}$ and $\mathrm{N}$ among them is not considered.

More detailed studies on organic matter use methods or techniques that involve physical and/or chemical fractionation for the determination of their different compartments or fractions (Von Lützow et al., 2007). Regarding the most common types of SOM fractionation, we stress the chemical method: extraction of soil humic substances (HS) and subsequent separation of their main components - humic acids, fulvic acids and humin fractions (Stevenson, 1994; Roscoe and Machado, 2002; Silva and Mendonça, 2007; Von Lützow et al., 2007); as for the physical methods, they are based on the differences between particle size (granulometric methods) or density between the compartments (densimetric methods), and a combination of the 
two methods can be used (Elliott and Cambardella, 1991; Roscoe and Machado, 2002).

The relative distribution of these fractions in the soil (obtained by physical and chemical fractionation methods) - as well as of its $\mathrm{C}$ and $\mathrm{N}$ levels - may identify soil organic matter quality, as well as reflect changes in environmental management and quality (Cunha et al., 2005), making it possible, among other aspects and purposes, to detect and assess any impacts caused by management practices and types of soil use.

Thus, the present study aimed to assess soil organic matter in soils of wet areas (veredas) located in preserved and disturbed environments (under the influence of agricultural and livestock activities), in the central region of the Cerrado biome.

\section{MATERIAL AND METHODS}

The study was conducted in the central region of the Cerrado biome, in the State of Goias, in veredas located in the city of Bela Vista de Goias, State of Goias. Soil was sampled in July and August 2012 (during the dry season), in areas between latitudes $16^{\circ} 48^{\prime} \mathrm{S}$ and $17^{\circ} 02^{\prime} \mathrm{S}$ and longitudes $48^{\circ} 41^{\prime} \mathrm{W}$ and $48^{\circ} 49^{\prime} \mathrm{W}$.

The climate in the region is tropical rainy (of Aw type, according to the Köppen classification), with an average annual rainfall of $1,500 \mathrm{~mm}$. There is a marked seasonal pattern in rainfall, with well defined rainy (spring and summer) and dry (autumn and winter) seasons (CPRM, 2001). The relief in the sampling sites is flat to gently undulating, with elevations ranging from 910 to $950 \mathrm{~m}$, between the different veredas.

Three areas located in the same sub-basin, in preserved and disturbed environments, were selected for soil sampling namely: a preserved vereda, surrounded by natural vegetation (cerrado); a disturbed vereda, surrounded by pasture and another disturbed vereda surrounded by annual crops (agriculture). At the time of the study, the entire peripheral region of the vereda located in the preserved environment was covered by natural Cerrado vegetation (in a restricted sense), i.e. savanna phytophysiognomies, typical of the Cerrado region (Ribeiro and Walter, 1998).

Regarding the study areas in disturbed environments, in the sampling period, one was surrounded by cultivated pastures, predominantly Brachiaria sp., while the other area was surrounded by grain crops (especially corn and soybean crops) in a no-tillage system. These disturbed veredas were not surrounded by the strip of preserved natural vegetation of the PPA.

\section{Sampling and soil characterization}

Soil samples were collected within the boundaries of the veredas under study, which were defined by distinct vegetation observed in the wet environment of the veredas and the dry adjacent areas, and also by the presence of saturated soils in rainy months (hydromorphic soils). Collections were made in a zigzag along reference lines arranged according to their position in the landscape (upper, mid and lower thirds of one of the slopes), according to the approximated direction of drainage of the vereda.

The samples were collected from two soil layers (0-10 and 10-20 cm) with a Dutch auger. Each sample was composed of five subsamples obtained along the reference lines for sampling, with soil collected in the upper region of the area close to the boundary or top of the vereda, at the middle position (middle) and at the lowest slope position, near the valley bottom.

Soil chemical properties and granulometric fractions were determined according to procedures recommended by Embrapa (1999) and are shown in table 1.

\section{Fractionation of soil organic matter}

The soil samples were air-dried and sieved $(<2 \mathrm{~mm})$ to obtain air-dried fine earth (ADFE). Total organic carbon was analyzed by the Walkley-Black method through wet oxidation of organic matter with potassium dichromate in sulfuric acid medium, without external heat source and titration with ferrous ammonium sulphate. The total nitrogen content (TN) of soil was determined by steam distillation (Kjeldahl) (Embrapa, 1997).

Physical fractionation (granulometry) of organic matter was performed according to Cambardella and Elliott (1992), with adjustments in the weight of the sample used for analysis (Bayer et al., 2004; Bongiovanni and Lobartini, 2006). To $20 \mathrm{~g}$ of ADFE, $70 \mathrm{~mL}$ of $5 \mathrm{~g} \mathrm{~L}^{-1}$ sodium hexametaphosphate $\left(\mathrm{NaPO}_{3}\right)_{\mathrm{n}}$ were added. The mixture was stirred for $15 \mathrm{~h}$ on a horizontal shaker at $130 \mathrm{rpm}$. At the end of the stirring process, the entire mixture was placed in a $53 \mu \mathrm{m}$ sieve and washed with distilled water. The material retained on the sieve, consisting of organic waste (as well as sand fraction), was defined as particulate organic matter - POM (organic particles $>53 \mu \mathrm{m}$ and up to $2 \mathrm{~mm}$ ). This material was oven-dried at $50{ }^{\circ} \mathrm{C}$, for $72 \mathrm{~h}$, and subsequently ground in a porcelain mortar and sieved $(<0.149 \mathrm{~mm})$. Then, $0.5 \mathrm{~g}$ aliquots were analyzed for their organic C levels, in a similar process as used for TOC (Embrapa, 1997), for the determination of particulate organic carbon (POC). 
Table 1. Chemical properties and soil texture at different slope positions, layers (depths) of sampling and conditions of use of the surrounding areas of the veredas (USAV)

\begin{tabular}{|c|c|c|c|c|c|c|c|c|c|c|c|c|c|c|c|c|}
\hline USAV & $\mathrm{pH}\left(\mathrm{CaCl}_{2}\right)$ & $\mathbf{P}$ & $\mathbf{K}$ & $\mathbf{C u}$ & $\mathbf{F e}$ & Mn & $\mathbf{Z n}$ & $\mathrm{Ca}^{2+}$ & $\mathrm{Mg}^{2+}$ & $\mathrm{Al}^{3+}$ & $\mathrm{H}+\mathrm{Al}$ & CEC & SOM & Clay & Silt & Sand \\
\hline & & \multicolumn{6}{|c|}{$\mathrm{mg} \mathrm{dm}^{-3}$} & \multicolumn{5}{|c|}{$\mathrm{cmol}_{\mathrm{c}} \mathrm{dm}^{-3}$} & \multicolumn{4}{|c|}{$\mathrm{g} \mathrm{kg}^{-1}$} \\
\hline & \multicolumn{16}{|c|}{ Upper border of the veredas (upper third of the slope) } \\
\hline & \multicolumn{16}{|c|}{$0-10 \mathrm{~cm}$} \\
\hline Preserved & 4.7 & 0.3 & 30.7 & 1.7 & 172.9 & 2.1 & 0,5 & 0.2 & 0.1 & 0.6 & 5.3 & 5.7 & 27.0 & 393 & 130 & 477 \\
\hline Pasture & 4.6 & 0.3 & 33.0 & 1.6 & 254.0 & 4.0 & 0,5 & 0.3 & 0.2 & 0.3 & 4.0 & 4.6 & 25.0 & 340 & 190 & 470 \\
\hline \multirow[t]{2}{*}{ Agriculture } & 5.5 & 0.9 & 42.7 & 1.8 & 190.9 & 5.2 & 0,8 & 0.3 & 0.1 & 0.3 & 3.6 & 4.1 & 34.0 & 387 & 170 & 443 \\
\hline & \multicolumn{16}{|c|}{$10-20 \mathrm{~cm}$} \\
\hline Preserved & 4.7 & 0.3 & 28.3 & 1.8 & 60.3 & 1.2 & 0,2 & 0.2 & 0.1 & 0.5 & 5.1 & 5.5 & 19.0 & 393 & 140 & 467 \\
\hline Pasture & 4,7 & 0.3 & 27.7 & 1.7 & 184.3 & 2.7 & 0,3 & 0.2 & 0.1 & 0.3 & 3.5 & 3.9 & 20.0 & 333 & 177 & 490 \\
\hline \multirow[t]{3}{*}{ Agriculture } & 5.6 & 0.3 & 38.7 & 1.4 & 111.0 & 3.4 & 0,6 & 0.2 & 0.1 & 0.2 & 3.2 & 3.6 & 20.0 & 390 & 160 & 450 \\
\hline & \multicolumn{16}{|c|}{ Middle of the veredas (middle third of the slope) } \\
\hline & \multicolumn{16}{|c|}{$0-10 \mathrm{~cm}$} \\
\hline Preserved & 4.8 & 0.3 & 32.3 & 2.0 & 127.0 & 1.7 & 0.3 & 0.2 & 0.1 & 0.8 & 5.2 & 5.5 & 40.0 & 390 & 140 & 470 \\
\hline Pasture & 4.5 & 0.3 & 35.7 & 1.6 & 292.7 & 2.7 & 1.7 & 0.2 & 0.1 & 0.3 & 5.1 & 5.5 & 37.0 & 387 & 150 & 463 \\
\hline \multirow[t]{2}{*}{ Agriculture } & 5.3 & 0.4 & 35.7 & 2.1 & 199.8 & 3.6 & 1.2 & 0.2 & 0.1 & 0.2 & 3.2 & 3.7 & 26.0 & 367 & 173 & 460 \\
\hline & \multicolumn{16}{|c|}{$10-20 \mathrm{~cm}$} \\
\hline Preserved & 4.5 & 0.3 & 29.3 & 1.7 & 51.9 & 0.8 & 0.5 & 0.2 & 0.1 & 0.9 & 6.4 & 6.7 & 28.0 & 393 & 137 & 470 \\
\hline Pasture & 4.6 & 0.3 & 43.0 & 1.6 & 222.1 & 1.3 & 0.8 & 0.2 & 0.1 & 0.4 & 4.6 & 5.0 & 26.0 & 393 & 163 & 443 \\
\hline \multirow[t]{3}{*}{ Agriculture } & 5.2 & 0.7 & 32.0 & 1.9 & 60.4 & 3.6 & 0.4 & 0.2 & 0.1 & 0.0 & 2.7 & 3.1 & 16.0 & 380 & 207 & 413 \\
\hline & \multicolumn{16}{|c|}{ Bottom of the veredas (lower third of the slope) } \\
\hline & \multicolumn{16}{|c|}{$0-10 \mathrm{~cm}$} \\
\hline Preserved & 4.9 & 0.7 & 48.3 & 1.4 & 92.4 & 1.6 & 1.4 & 0.2 & 0.1 & 0.8 & 6.8 & 7.3 & 63.0 & 387 & 143 & 470 \\
\hline Pasture & 5.4 & 0.3 & 56.0 & 1.7 & 212.8 & 1.5 & 2.5 & 0.2 & 0.1 & 0.6 & 4.4 & 4.8 & 69.0 & 400 & 133 & 467 \\
\hline \multirow[t]{2}{*}{ Agriculture } & 4.6 & 0.3 & 30.0 & 1.8 & 170.0 & 2.5 & 0.2 & 0.2 & 0.1 & 0.4 & 4.5 & 4.8 & 29.0 & 350 & 183 & 467 \\
\hline & \multicolumn{16}{|c|}{$10-20 \mathrm{~cm}$} \\
\hline Preserved & 4.9 & 0.8 & 31.3 & 1.6 & 123.6 & 1.9 & 1.1 & 0.2 & 0.1 & 0.9 & 6.4 & 6.7 & 73.0 & 383 & 130 & 487 \\
\hline Pasture & 5.2 & 0.3 & 31.3 & 1.5 & 136.1 & 2.9 & 1.8 & 0.2 & 0.1 & 0.6 & 4.2 & 4.5 & 69.0 & 413 & 113 & 473 \\
\hline Agriculture & 4.4 & 0.3 & 30.3 & 1.7 & 142.5 & 2.8 & 0.3 & 0.2 & 0.1 & 0.3 & 5.1 & 5.5 & 27.0 & 383 & 177 & 440 \\
\hline
\end{tabular}

Analyses for the nitrogen content in particulate organic matter (NPOM) were performed by dry combustion on a CHNS elemental analyzer (model PE 2400, Series II CHNS/O, Perkin Elmer, Norwalk, USA). The carbon and oxygen of the organic matter associated to the minerals (OCM and NM) were calculated by the difference between TOC and POC and TN and NMOP, levels, respectively.

The humic fractions of organic matter (fulvic acids, humic acids and humins) were determined by the method described by Mendonça and Matos (2005).

\section{Experimental design and statistical analyses}

The data were subjected to analysis of variance to identify the effects of the different environmental conditions on the assessed variables. Thus, a randomized block design and band structure in a $3 \times 3$ factorial arrangement (three types of use of surrounding areas and three slope positions) were used. The Tukey test $(p<0.05)$ was used for mean comparison and SAS (Statistical Analysis System) software, version 9.1 (SAS, 2003) in the analyses.

\section{RESULTS AND DISCUSSION}

The TOC contents varied according to the effect of the slope position of the vereda (toposequence) and the use of the adjacent land (Table 2). For 0-10 cm layer, in the lower slope positions (middle and bottom), TOC contents were lowest in the vereda adjacent to agricultural areas, and no differences were detected between the preserved and the pasture environments (Table 2). However, in the 10-20 cm layer, relatively lower TOC contents were observed only at the bottom of the slope. At the upper border of the veredas, in both soil depths of the sample, on the contrary, TOC contents were higher in the area adjacent to crops (agriculture), without 
significant differences between the other types of soil use. In both sampled layers, highest TOC contents were observed in the lowest slope positions (bottom), at all study locations. In the preserved area and in the area surrounded by pastures, in the $0-10 \mathrm{~cm}$ layer, there was a progressive increase in TOC contents from the upper border to the bottom of the slopes (Table 2). The cultivation practices, as well as other anthropic activities, affect soil biogeochemical processes in humid agricultural areas (Neue et al., 1997), impacting the dynamics of SOM and of elements such as $\mathrm{C}$ and $\mathrm{N}$.

In a previous study at the same locations, though with soil sampling in the rainy season, SOM was higher in the preserved vereda than in the cultivated area, with intermediate values in the area surrounded by pastures (Sousa et al., 2011). Also, a significant decrease in soil C contents was observed by Wantzen et al. (2012), especially in veredas and gallery forests in the Cerrado biome, as a result of anthropic disturbances and changes in land use.

In their comparison of the natural and disturbed areas of an adjacent vereda with pastures in the Cerrado biome in Minas Gerais, Guimarães et al. (2002) did not detect changes in organic matter contents in soils at the upper border of the vereda. However, in the lowest slope positions (sampled to a depth of $16 \mathrm{~cm}$ ) higher or equivalent TOC contents were observed in a vereda surrounded by pasture (disturbed) compared to preserved veredas.

Specifically at the lowest slope position, in both soil layers, $\mathrm{N}$ contents were highest in the vereda surrounded by pasture and lowest in that adjacent to agricultural fields, while the preserved vereda had intermediate values (Table 2). No significant

Table 2. Total organic carbon (TOC), total nitrogen (TN), soil C:N ratio (TOC:TN), particulate organic carbon (POC), nitrogen of particulate organic matter (NPOM) and particulate organic carbon by total organic carbon (POC:TOC) at different slope (relief) positions and conditions of use of the surrounding areas, in the 0-10 and 10-20 cm layers

\begin{tabular}{|c|c|c|c|c|c|c|}
\hline Slope position & Preserved & Pasture & Agriculture & Preserved & Pasture & Agriculture \\
\hline & & TOC (g kg-1) & & & POC (g kg-1) & \\
\hline & \multicolumn{6}{|c|}{$0-10 \mathrm{~cm}$} \\
\hline Upper & $20.1 \mathrm{cB}$ & $20.5 \mathrm{cB}$ & $26.7 \mathrm{abA}$ & $3.8 \mathrm{bB}$ & $7.3 \mathrm{bB}$ & $15.7 \mathrm{aA}$ \\
\hline Middle & $29.1 \mathrm{bA}$ & $24.5 \mathrm{bAB}$ & $21.5 \mathrm{bB}$ & $6.6 \mathrm{bB}$ & $8.8 \mathrm{bAB}$ & $10.1 \mathrm{aA}$ \\
\hline \multirow[t]{2}{*}{ Lower } & $73.1 \mathrm{aA}$ & $77.7 \mathrm{aA}$ & $34.7 \mathrm{aB}$ & $34.9 \mathrm{aB}$ & $50.4 \mathrm{aA}$ & $12.7 \mathrm{aC}$ \\
\hline & \multicolumn{6}{|c|}{$10-20 \mathrm{~cm}$} \\
\hline Upper & $16.1 \mathrm{bB}$ & $15.5 \mathrm{bB}$ & $21.7 \mathrm{bA}$ & $1.7 \mathrm{bB}$ & $3.1 \mathrm{bAB}$ & $5.3 \mathrm{aA}$ \\
\hline Middle & $20.6 \mathrm{bA}$ & $18.0 \mathrm{bA}$ & $16.3 \mathrm{cA}$ & $3.5 \mathrm{bA}$ & $4.7 \mathrm{bA}$ & $6.2 \mathrm{aA}$ \\
\hline \multirow[t]{3}{*}{ Lower } & $71.1 \mathrm{aA}$ & $67.4 \mathrm{aA}$ & $29.0 \mathrm{aB}$ & $15.6 \mathrm{aB}$ & $53.6 \mathrm{aA}$ & $7.3 \mathrm{aB}$ \\
\hline & & $\mathrm{TN}\left(\mathrm{g} \mathrm{kg}^{-1}\right)$ & & & NPOM $\left(\mathrm{g} \mathrm{kg}^{-1}\right)$ & \\
\hline & \multicolumn{6}{|c|}{$0-10 \mathrm{~cm}$} \\
\hline Upper & $3.0 \mathrm{bA}$ & $2.3 \mathrm{bA}$ & $2.6 \mathrm{aA}$ & $0.1 \mathrm{aB}$ & $0.2 \mathrm{bAB}$ & $0.3 \mathrm{aA}$ \\
\hline Middle & $2.8 \mathrm{Ba}$ & $2.2 \mathrm{bA}$ & $3.1 \mathrm{aA}$ & $0.1 \mathrm{aB}$ & $0.3 \mathrm{bA}$ & $0.2 \mathrm{aAB}$ \\
\hline \multirow[t]{2}{*}{ Lower } & $5.2 \mathrm{Ab}$ & $8.2 \mathrm{aA}$ & $2.2 \mathrm{aC}$ & $1.3 \mathrm{aB}$ & $3.1 \mathrm{aA}$ & $0.4 \mathrm{aB}$ \\
\hline & \multicolumn{6}{|c|}{$10-20 \mathrm{~cm}$} \\
\hline Upper & $2.6 \mathrm{aA}$ & $1.9 \mathrm{bB}$ & $2.4 \mathrm{aA}$ & $0.1 \mathrm{aB}$ & $0.1 \mathrm{aB}$ & $0.2 \mathrm{aA}$ \\
\hline Middle & $2.6 \mathrm{aA}$ & $2.1 \mathrm{bA}$ & $2.0 \mathrm{aA}$ & $0.1 \mathrm{aA}$ & $0.1 \mathrm{aA}$ & $0.2 \mathrm{aA}$ \\
\hline \multirow[t]{3}{*}{ Lower } & $4.1 \mathrm{aAB}$ & $6.9 \mathrm{aA}$ & $2.3 \mathrm{aB}$ & $0.3 \mathrm{aA}$ & $1.6 \mathrm{aA}$ & $0.3 \mathrm{aA}$ \\
\hline & & TOC:TN (\%) & & & POC:TOC (\%) & \\
\hline & \multicolumn{6}{|c|}{$0-10 \mathrm{~cm}$} \\
\hline Upper & $6.65 \mathrm{bB}$ & $8.96 \mathrm{aAB}$ & $10.41 \mathrm{bA}$ & $18.77 \mathrm{bB}$ & $35.81 \mathrm{bB}$ & $58.78 \mathrm{aA}$ \\
\hline Middle & $10.23 \mathrm{abA}$ & $11.28 \mathrm{aA}$ & $7.13 \mathrm{cA}$ & $22.65 \mathrm{bC}$ & $36.04 \mathrm{bB}$ & $46.83 \mathrm{abA}$ \\
\hline \multirow[t]{2}{*}{ Lower } & $14.25 \mathrm{aA}$ & $9.48 \mathrm{aB}$ & $15.85 \mathrm{aA}$ & $47.81 \mathrm{aB}$ & $64.97 \mathrm{aA}$ & $35.86 \mathrm{bC}$ \\
\hline & \multicolumn{6}{|c|}{$10-20 \mathrm{~cm}$} \\
\hline Upper & $6.13 \mathrm{bB}$ & $8.08 \mathrm{aAB}$ & $8.94 \mathrm{bA}$ & $10.57 \mathrm{aB}$ & $19.80 \mathrm{bAB}$ & $24.26 \mathrm{bA}$ \\
\hline Middle & $8.28 \mathrm{bA}$ & $8.57 \mathrm{aA}$ & $8.12 \mathrm{bA}$ & $16.82 \mathrm{aA}$ & $26.66 \mathrm{bA}$ & $37.69 \mathrm{aA}$ \\
\hline Lower & $17.79 \mathrm{aA}$ & $10.12 \mathrm{aB}$ & $12.51 \mathrm{aAB}$ & $21.89 \mathrm{aB}$ & $79.13 \mathrm{aA}$ & $24.95 \mathrm{bB}$ \\
\hline
\end{tabular}

In the same layer, lowercase letters compare slope positions (columns) and uppercase letters compare the uses of the surrounding areas (lines). Means followed by the same letter do not differ statistically by Tukey test $(\mathrm{p}<0.05)$. 
differences in this regard were detected between the top and the mid-slope of the veredas, in the topsoil (surface soil) layer, and no differences in TN content between the different environments or soil uses in these three slope positions (Table 2).

Studies in Brazilian tropical soils (in the Cerrado biome and the Amazon) showed a tendency of decreasing TOC and TN contents in agricultural and agroforestry systems, or areas disturbed by deforestation or other types of land use, compared to similar soils covered by native vegetation (Longo and Espíndola, 2000; Wendling et al., 2011). Depletion of TOC and TN in surface soil from agricultural land were also observed in hydromorphic soil in areas of subtropical climate in southern Brazil compared to preserved environments (Santos et al., 2004).

However, depletion can also occur under tropical conditions, when TN and TOC in pasture areas are equivalent to or higher than the levels in environments covered by native vegetation (Islam and Weil, 2000; Groffman et al., 2001). Under certain circumstances, TOC and TN contents can be higher in pasture soils than in forest areas. Apparently, the nature of plant tissues and organic waste of pasture grasses (especially root biomass), as well as the type of decomposition, which is relatively slower and associated to a possible inhibition of nitrification in these environments, determine increased organic activity and a more efficient contribution to humus formation than forest leaf litter, ensuring the maintenance of relatively high levels of $\mathrm{N}$ and $\mathrm{C}$ in the soil (Stevenson, 1994; Brady and Weil, 2008).

In this study, part of the pasture area was under intensive irrigated pasture with grazing rotation for milk production, for a period of approximately eight years, with regular applications of nitrogen fertilizers (topdressing). Excessive rates or applications under unfavorable or unsuitable conditions can cause loss of $\mathrm{N}$, which, transferred to other sites or ecosystems becomes a pollutant element (Cantarella, 2007), degrading the environmental quality.

Humid areas (and veredas) can assimilate nitrate from agricultural areas, promoting its incorporation in vegetation (and microbial) tissues or in SOM, in organic $\mathrm{N}$ forms. These areas, as well as riparian zones of springs and water courses, are considered $\mathrm{N}$ drains (collectors and dissipators) with a great capacity to remove reactive $\mathrm{N}$ forms from the environment, thus preventing this element from moving in nearby habitats and ecosystems or, in many cases, absorbing large amounts of $\mathrm{N}$ from adjacent areas (Robertson and Groffman, 2007).

There were no changes in the $\mathrm{C}: \mathrm{N}$ ratio in all relief (slope) positions in the area surrounded by pasture, at the two depths (soil layers) studied, while in the preserved and agricultural areas the highest values for this ratio were found in the bottom region (Table 2). This higher $\mathrm{C}: \mathrm{N}$ ratio at the bottom of the slopes in the veredas confirms the influence of the hydromorphic environment in reducing the humification process, with the accumulation of organic materials in the early stages of decomposition, in contrast to what occurs in the areas surrounding the veredas, where there is a predominance of aerated soils that allow significant decomposition of SOM, reducing the C:N ratio.

Similar findings were reported by Ramos (2000) in hydromorphic soils of veredas in the Cerrado of Minas Gerais, where the C:N ratio ranged from 8 to 24, and in the lower third of the slopes this ratio was approximately 2 to 2.5 times higher than in the higher positions of the slope (mid and upper thirds).

Except for the vereda surrounded by crops (cultivated area), high POC contents were observed at the bottom of the other veredas, which characterized them as regions with $\mathrm{C}$ accumulation, especially in the form of partially decomposed organic matter (Table 2). Despite the high POC contents in the vereda positions close to the agricultural areas (medium and upper thirds), the agricultural activity reduced POC contents at the bottom of the veredas drastically, which demonstrates that the impact of agricultural activity is more significant in the section of the vereda that should be best preserved.

In semi-arid southern African savanna, higher POM and TOC contents were also found in natural pastures and undisturbed savanna areas than in agricultural and horticultural areas, to a soil depth of $20 \mathrm{~cm}$, and there were no differences for these properties between soils of pastures and under native vegetation cover (Materechera, 2014).

In many studies, POC contents are more sensitive to changes in soil use than TOC, and agricultural areas are generally more degraded than those under native vegetation (Figueiredo et al., 2010; Salton et al., 2011). Pastures form large amounts of POC, mostly because of the extensive root system and aerial biomass of foraging plants (Franzluebbers and Stuedemann, 2002; Salton et al., 2011; Loss et al., 2012). In a study of Salton et al. (2011), pasture systems contained higher levels of POC than soils under natural vegetation or agricultural systems.

The POC:TOC ratio observed the same pattern as the POC contents. At the bottom of the veredas, highest POC:TOC ratios were observed in the vereda adjacent to pasture areas, and in the 0-10 $\mathrm{cm}$ layer, the POC:TOC ratio was lower in the area adjacent to agricultural crops. These results indicate that the decrease in TOC contents resulted from a decrease in POC, caused by agricultural activity in areas near the veredas.

The $\mathrm{N}$ contained in particulate organic matter (NPOM) was little affected by the different soil 
uses in the vicinity of the veredas. Only the vereda surrounded by pasture showed higher NPOM content in the lowest position, compared to the other slope positions. The absence of differences can be due to the high variability in NPOM levels, which makes a statistical distinction more difficult.

In general, the $\mathrm{C}$ from organic matter associated to minerals (OCM) constituted the largest reserve of $\mathrm{C}$ in the soils of the veredas. Although this $\mathrm{C}$ fraction is little affected by soil use, as indicated in some studies (Cambardella and Ellliott, 1992; Figueiredo et al., 2010), in this study, the preserved vereda soil had the highest OCM levels at all slope positions, with no differences between the ecosystems with disturbed surroundings (Table 3). Higher OCM levels in preserved veredas indicate that this fraction, which is more stabilized and has greater interaction with the mineral fraction, is also affected by anthropic use of soil nearby the veredas.

In the soil surface layer, at the upper border and mid-slope positions, there were no significant changes in $\mathrm{N}$ content of the organic matter associated to minerals (NM) between veredas surrounded by areas under different soil uses, although at the bottom of the slopes of the assessed environments, the highest NM levels were observed in the preserved area and in the area adjacent to pastures, with highest concentrations of this soil element at the bottom of the slopes. The highest $\mathrm{N}$ contents at the bottom of the preserved veredas are generally caused by the lower $\mathrm{C}: \mathrm{N}$ ratio usually found in this fraction of the SOM, which is more accumulated in natural/preserved areas (Table 3).

\section{Carbon in soil humic substances}

The bottom of the veredas has generally shown the highest $\mathrm{C}$ contents in all fractions of humified organic matter, characterizing an area with $\mathrm{C}$ accumulation. At the upper border of the veredas, which is closest to agricultural areas, the $\mathrm{C}$ contents detected in the fulvic acid fractions (FAF) in the two soil layers were higher than in the preserved area (Table 4).

At the bottom of the veredas, in both soil layers, the humic acid fraction (HAF) was lower in the environment closer to agricultural crops. In the medium third and at the bottom of the vereda, the humic acid (HAF) fractions of the pastures were similar to those in the preserved area and higher than those in the agricultural area.

At the surface $(0-10 \mathrm{~cm}$ layer) of Brazilian tropical soils (in the Cerrado biome), the $\mathrm{C}$ levels observed in the fulvic acid fractions and humic acid fractions in pasture soils were higher than in areas covered by native vegetation. This can be explained by the extensive root system and the wide spreading root system of forage grass in soil, which favors $\mathrm{C}$ deposition in the soil. Moreover, the intense root activity can also be related to other physical, chemical or biological mechanisms, including processes associated to mycorrhizal fungi, as well as chemical interactions with metal ions that result in higher levels of compounds, e.g., the fulvic and humic acids in soils of pasture areas (Ramos et al., 2013).

The agricultural land use promoted the highest $\mathrm{C}$ contents in the humin fraction of soil at the upper border of the vereda surrounded by agricultural areas (Table 4). In the medium position of the slope, however, no significant differences were observed between the different ecosystems or types of land use in the vicinity, while in the lowest position of the veredas (bottom), the lowest $\mathrm{C}$ levels in the humin fraction (HUM), in the $0-10 \mathrm{~cm}$ layer, were detected in the soils of the veredas surrounded by agricultural crops (Table 4), demonstrating that the impacts of agricultural activity are strongest at the bottom of the veredas.

In a study on tropical soils used for agricultural purposes in the Cerrado biome, in areas under conventional cultivation for grain production, it was found that the agricultural

Table 3. Organic carbon and nitrogen associated to minerals (OCM and NM, respectively) at different slope positions and influenced by different land uses of the surrounding areas, in the 0-10 and 10-20 cm layers

\begin{tabular}{lccc}
\hline Slope position & Preserved & Pasture & Agriculture \\
\hline & \multicolumn{3}{c}{$\begin{array}{c}0 \text { OCM }(\mathrm{g} \mathrm{kg}-1) \\
0-10 \mathrm{~cm}\end{array}$} \\
Upper & $16.3 \mathrm{bA}$ & $13.2 \mathrm{bAB}$ & $11.1 \mathrm{bB}$ \\
Middle & $22.5 \mathrm{bA}$ & $15.7 \mathrm{bB}$ & $11.4 \mathrm{bB}$ \\
Lower & $38.2 \mathrm{aA}$ & $27.2 \mathrm{aB}$ & $22.1 \mathrm{aB}$ \\
& & $10-20 \mathrm{~cm}$ & \\
Upper & $14.4 \mathrm{bAB}$ & $12.4 \mathrm{aB}$ & $16.4 \mathrm{bA}$ \\
Middle & $17.1 \mathrm{bA}$ & $13.3 \mathrm{aAB}$ & $10.2 \mathrm{cB}$ \\
Lower & $55.5 \mathrm{aA}$ & $13.8 \mathrm{aB}$ & $21.7 \mathrm{aB}$ \\
& & $\mathrm{NM}(\mathrm{g} \mathrm{kg}-1)$ & \\
& & $0-10 \mathrm{~cm}$ & \\
Upper & $2.9 \mathrm{bA}$ & $2.1 \mathrm{bA}$ & $2.3 \mathrm{aA}$ \\
Middle & $2.7 \mathrm{bA}$ & $1.9 \mathrm{bA}$ & $2.9 \mathrm{aA}$ \\
Lower & $3.9 \mathrm{aA}$ & $5.1 \mathrm{aA}$ & $1.8 \mathrm{aB}$ \\
& & $10-20 \mathrm{~cm}$ & \\
Upper & $2.5 \mathrm{aA}$ & $1.8 \mathrm{bB}$ & $2.2 \mathrm{aAB}$ \\
Middle & $2.5 \mathrm{aA}$ & $2.0 \mathrm{bA}$ & $1.9 \mathrm{aA}$ \\
Lower & $3.8 \mathrm{aA}$ & $5.3 \mathrm{aA}$ & $2.1 \mathrm{aB}$ \\
\hline In the & &
\end{tabular}

In the same layer, lowercase letters compare slope positions (columns) and uppercase letters compare land uses of the surrounding areas (lines). Means followed by the same letter do not differ statistically by Tukey test $(p<0.05)$. 
Table 4. Carbon of humic fractions of soil organic matter at different slope positions and influenced by different land uses of the surrounding areas, in the 0-10 and $10-20 \mathrm{~cm}$ layers

\begin{tabular}{|c|c|c|c|}
\hline Slope position & Preserved & Pasture & Agriculture \\
\hline & \multicolumn{3}{|c|}{ Fulvic acid fraction $\left(\mathrm{g} \mathrm{kg}^{-1}\right)$} \\
\hline & \multicolumn{3}{|c|}{$0-10 \mathrm{~cm}$} \\
\hline Upper & $2.7 \mathrm{bB}$ & $3.4 \mathrm{bAB}$ & $4.8 \mathrm{abA}$ \\
\hline Middle & $3.5 \mathrm{bA}$ & $3.8 \mathrm{bA}$ & $4.1 \mathrm{bA}$ \\
\hline \multirow[t]{2}{*}{ Lower } & $5.1 \mathrm{aB}$ & $6.7 \mathrm{aA}$ & $5.4 \mathrm{aB}$ \\
\hline & \multicolumn{3}{|c|}{$10-20 \mathrm{~cm}$} \\
\hline Upper & $2.0 \mathrm{bC}$ & $2.8 \mathrm{bB}$ & $3.8 \mathrm{aA}$ \\
\hline Middle & $2.7 \mathrm{abA}$ & $3.3 \mathrm{bA}$ & $3.5 \mathrm{aA}$ \\
\hline \multirow[t]{3}{*}{ Lower } & $3.8 \mathrm{aB}$ & $6.5 \mathrm{aA}$ & $4.6 \mathrm{aB}$ \\
\hline & \multicolumn{3}{|c|}{ Humic acid fraction ( $\left.\mathrm{g} \mathrm{kg}^{-1}\right)$} \\
\hline & \multicolumn{3}{|c|}{$0-10 \mathrm{~cm}$} \\
\hline Upper & $4.1 \mathrm{cAB}$ & $3.8 \mathrm{cB}$ & $5.6 \mathrm{bA}$ \\
\hline Middle & $8.1 \mathrm{bA}$ & $6.0 \mathrm{bAB}$ & $3.7 \mathrm{bB}$ \\
\hline \multirow[t]{2}{*}{ Lower } & $13.5 \mathrm{aA}$ & $13.8 \mathrm{aA}$ & $8.8 \mathrm{aB}$ \\
\hline & \multicolumn{3}{|c|}{$10-20 \mathrm{~cm}$} \\
\hline Upper & $3.5 \mathrm{bA}$ & $3.6 \mathrm{bA}$ & $4.4 \mathrm{bA}$ \\
\hline Middle & $6.0 \mathrm{bA}$ & $4.8 \mathrm{bAB}$ & $2.9 \mathrm{bB}$ \\
\hline \multirow[t]{3}{*}{ Lower } & $12.6 \mathrm{aAB}$ & $14.6 \mathrm{aA}$ & $7.8 \mathrm{aB}$ \\
\hline & \multicolumn{3}{|c|}{ Humin ( $\left.\mathrm{g} \mathrm{kg}^{-1}\right)$} \\
\hline & \multicolumn{3}{|c|}{$0-10 \mathrm{~cm}$} \\
\hline Upper & $4.5 \mathrm{cB}$ & $7.8 \mathrm{bA}$ & $9.3 \mathrm{bA}$ \\
\hline Middle & $11.6 \mathrm{bA}$ & $9.6 \mathrm{bA}$ & $7.1 \mathrm{bA}$ \\
\hline \multirow[t]{2}{*}{ Lower } & $27.9 \mathrm{aA}$ & $25.6 \mathrm{aA}$ & $13.4 \mathrm{aB}$ \\
\hline & \multicolumn{3}{|c|}{$10-20 \mathrm{~cm}$} \\
\hline Upper & $3.3 \mathrm{bC}$ & $5.3 \mathrm{bB}$ & $8.4 \mathrm{bA}$ \\
\hline Middle & $6.1 \mathrm{bA}$ & $6.0 \mathrm{bA}$ & $5.9 \mathrm{bA}$ \\
\hline \multirow[t]{3}{*}{ Lower } & $15.9 \mathrm{aB}$ & $22.6 \mathrm{aA}$ & $11.8 \mathrm{aB}$ \\
\hline & \multicolumn{3}{|c|}{ HAF:FAF } \\
\hline & \multicolumn{3}{|c|}{$0-10 \mathrm{~cm}$} \\
\hline Upper & $1.55 \mathrm{bA}$ & $1.11 \mathrm{bB}$ & $1.17 \mathrm{abB}$ \\
\hline Middle & $2.33 \mathrm{abA}$ & $1.59 \mathrm{aAB}$ & $0.91 \mathrm{bB}$ \\
\hline \multirow[t]{2}{*}{ Lower } & $2.67 \mathrm{aA}$ & $2.05 \mathrm{aB}$ & $1.63 \mathrm{aB}$ \\
\hline & \multicolumn{3}{|c|}{$10-20 \mathrm{~cm}$} \\
\hline Upper & $1.75 \mathrm{bA}$ & $1.28 \mathrm{aA}$ & $1.17 \mathrm{abA}$ \\
\hline Middle & $2.24 \mathrm{bA}$ & $1.47 \mathrm{aAB}$ & $0.82 \mathrm{bB}$ \\
\hline Lower & $3.36 \mathrm{aA}$ & $2.24 \mathrm{aB}$ & $1.70 \mathrm{aB}$ \\
\hline
\end{tabular}

In the same layer, lowercase letters compare slope positions (columns) and uppercase letters compare land uses of the surrounding areas (lines). Means followed by the same letter do not differ statistically by the Tukey test $(\mathrm{p}<0.05)$ activity favored the increase of fulvic acids and humin and the decrease of humic acids, compared to soils covered by native vegetation (Cunha et al., 2001). Also in the Cerrado biome, in a comparison of similar soils in pastoral environment and under native savanna vegetation, down to $20 \mathrm{~cm}$, Pulrolnik et al. (2009) found higher $\mathrm{C}$ levels in the humic acid fractions (HAF) in the pasture area and equivalent levels for FAF and HUM between the different conditions assessed.

The HAF:FAF ratio was generally higher in the preserved ecosystem, especially in the mid and lower slope positions, indicating the possible occurrence of more evolved and humified organic matter, with a relative predominance of humic acid (over FAF), and, thus, considerable resistance to microbial degradation (Silva and Mendonça, 2007; Brady and Weil, 2008). In turn, the agricultural use of soil in the adjacent areas promoted a decrease in the HAF:FAF ratio at all slope positions of the vereda.

Compared to other soil types, hydromorphic soils are relatively rich in humic acids, often at a HAF:FAF ratio $>1$, and can also present some characteristics related to the presence of humus with a high degree of maturation. In general, the HAF:FAF ratio can be considered an indicator of the humus quality, with lower ratios expected in more weathered soils. Humic acids, in turn, are considered markers of the humification process, reflecting both the condition of soil formation (pedogenetic process), as well as soil management aspects (Cunha et al., 2005).

A toposequence of a Brazilian tropical soil showed that limited drainage in the lower third of the slope and a more intense vertical water flow favored polycondensation reactions of organic compounds, with increasing HAF:FAF ratio slopedownwards towards the areas with hydromorphic soils (Canellas et al., 2000). These authors stressed that the position in the toposequence affects water dynamics, which in turn determine the contents of SOM fractions, particularly the free fulvic acid fractions and fulvic acids transported by the lateral and vertical water flow in the slope.

Therefore, quantitative analyses of soluble humic substances and other organic fractions in the soil in humid areas may help estimate the levels and global stability of organic matter in ecosystems (Pant et al., 2003). The use of the relative distribution of organic matter fractions as an indicator of changes in soil management or environmental quality is widely confirmed in the literature. Thus, analysis of soil quality based on SOM properties and features can reflect the results of the process of soil formation and of the impacts of land uses and soil management practices (Cunha et al., 2005; Figueiredo et al., 2013; Guimarães et al., 2013). 


\section{CONCLUSIONS}

In general, the agricultural use of land surrounding the veredas reduced carbon and nitrogen contents of particulate organic matter, especially in the lower part of the slope (relief).

Considering all properties together, the decreases in carbon and nitrogen content were highest in the lowest part of the vereda, which is therefore the most susceptible area to changes caused by agricultural practices in the vicinity of the veredas.

Soil organic $\mathrm{C}$ and $\mathrm{N}$ contents and labile and stable soil carbon fractions of SOM, such as POC, OCM and HAF:FAF, especially at the slope bottom (lower slope position) can be good indicators of the environmental changes promoted by different land uses in the veredas.

\section{ACKNOWLEDGEMENTS}

The authors are indebted to the Foundation for Research Support of the State of Goiás (FAPEG), for a $\mathrm{PhD}$ scholarship to the first author. They also wish to thank the Laboratories of Soil Microbiological and Biochemical Analyses and the Laboratories of Soil and Foliar Analyses of Escola de Agronomia da Universidade Federal de Goiás (LASF/EA/UFG), the Laboratory of Studies of Soil Organic Matter of Faculdade de Agronomia e Medicina Veterinária da Universidade de Brasília (LAbMOS/FAV/UnB), to the Laboratory of Agri-Environmental Analyzes (LAA) of Embrapa Arroz e Feijão and the Foundation for Research Support (FUNAPE/UFG) for financial, material and technical support.

\section{REFERENCES}

Bastida F, Zsolnay A, Hernández T, García C. Past, present and future of soil quality indices: A biological perspective. Geoderma. 2008;147:159-71.

Batlle-Bayer L, Batjes NH, Bindraban PS. Changes in organic carbon stocks upon land use conversion in the Brazilian Cerrado: A review. Agric Ecosyst Environ. 2010;137:47-58.

Bayer C, Martin-Neto L, Mielniczuk J, Pavinato A. Armazenamento de carbono em frações lábeis da matéria orgânica de um Latossolo Vermelho sob plantio direto. Pesq Agropec Bras. 2004;39:677-83.

Bongiovanni MD, Lobartini JC. Particulate organic matter, carbohydrate, humic acid contents in soil macro- and microaggregates as affected by cultivation. Geoderma. 2006;136:660-5.

Brady NC, Weil RR. The nature and properties of soils. $14^{\text {th }}$ ed. Upper Saddle River: Pearson Prentice Hall; 2008.
Burbridge PR. Integrated planning and management of freshwater habitats, including wetlands. Hydrobiologia. 1994;285:311-22.

Cambardella CA, Elliott ET. Particulate soil organic-matter changes across a grassland cultivation sequence. Soil Sci Soc Am J. 1992;56:777-83.

Canellas LP, Berner PG, Silva SG, Silva MB, Santos GA. Frações da matéria orgânica em seis solos de uma topossequência no Estado do Rio de Janeiro. Pesq Agropec Bras. 2000;35:133-43.

Cantarella, H. Nitrogênio. In: Novais RF, Alvarez V VH, Barros NF, Fontes RLF, Cantarutti RB, Neves JCL, editores. Fertilidade do solo. Viçosa, MG: Sociedade Brasileira de Ciência do Solo; 2007. p.375-470.

Carvalho JLN, Raucci GS, Cerri CEP, Bernoux M, Feigl BJ, Wruck J, Cerri, CC. Impact of pasture, agriculture and crop-livestock systems on soil C stocks in Brazil. Soil Till Res. 2010;110:175-86.

Companhia de Pesquisa de Recursos Minerais - CPRN. Serviço Geológico do Brasil. Programa Levantamentos Geológicos Básicos do Brasil. Brasília, DF: Companhia de Pesquisa de Recursos Minerais; 2001. (Folha SE. 22 Goiânia).

Cunha TJF, Canellas LP, Santos GA, Ribeiro LP. Fracionamento da matéria orgânica humificada de solos brasileiros. In: Canellas LP, Santos GA, editores. Humosfera: Tratado preliminar sobre a química das substâncias húmicas. Campos dos Goytacazes: Universidade Estadual do Norte Fluminense; 2005. p.54-80.

Cunha TJF, Macedo JR, Ribeiro LP, Palmieri F, Freitas PL, Aguiar AC. Impacto do manejo convencional sobre propriedades físicas e substâncias húmicas de solos sob cerrado. Ci Rural. 2001;31:27-36.

Ebeling AG, Espindula Jr. A, Valladares GS, Anjos LHC, Pereira MG. Propriedades químicas como indicadores ambientais em Organossolos do Estado do Rio de Janeiro. R Univ Rural. 2004;24:1-6.

Elliott ET, Cambardella CA. Physical separation of soil organic matter. Agric Ecosyst Environ. 1991;34:407-19.

Empresa Brasileira de Pesquisa Agropecuária - Embrapa. Manual de análises químicas de solos, plantas e fertilizantes. Brasília, DF: 1999

Empresa Brasileira de Pesquisa Agropecuária - Embrapa. Manual de métodos de análise de solo. $2^{a}$ ed. Rio de Janeiro: 1997.

Figueiredo CC, Resck DVS, Carneiro MAC. Labile and stable fractions of soil organic matter under management systems and native cerrado. $\mathrm{R}$ Bras Ci Solo. 2010;34:907-16.

Figueiredo CC, Resck DVS, Carneiro MAC, Ramos MLG, Sá JCM. Stratification ratio of organic matter pools influenced by management systems in a weathered Oxisol from a tropical agro-ecoregion in Brazil. Soil Res. 2013;51:133-41.

Franzluebbers AJ, Stuedemann JA. Particulate and non-particulate fractions of soil organic carbon under pastures in the Southern Piedmont USA. Environ Pollut. 2002;116:53-62.

Gregorich EG, Carter MR, Doran JW, Pankhurst CE, Dwyer LM. Biological attributes of soil quality. In: Gregorich EG, Carter MR, editors. Soil quality for crop production and ecosystem health. Wageningen: Elsevier; 1997. p.81-113.

Groffman PM, McDowell WH, Myers JC, Merriam JL. Soil microbial biomass and activity in tropical riparian forests. Soil Biol Biochem. 2001;33:1339-48. 
Guimarães AJM, Araújo GM, Corrêa GFC. Estrutura fitossosiológica em área natural e antropizada de uma vereda em Uberlândia, MG. Acta Bot Bras. 2002;16:317-29.

Guimarães DV, Gonzaga MIS, Silva TO, Silva TL, Dias NS, Matias MIS. Soil organic matter pools and carbon fractions in soil under different land uses. Soil Till Res. 2013;126:177-82.

Guo LB, Gifford RM. Soil carbon stocks and land use change: A meta analysis, Global Change Biol. 2002;8:345-60.

Houlahan JE, Keddy PA, Makkay K, Findlay CS. The effects of adjacent land use on wetland species richness and community composition. Wetlands. 2006;26:79-96.

Islam KR, Weil RR. Land use effects on soil quality in a tropical forest ecosystem of Bangladesh. Agric Ecosyst Environ. 2000;79:9-16.

Liu X, Herbert SJ, Hashemi AM, Zhang X, Ding G. Effects of agricultural management on soil organic matter and carbon transformation - a review. Plant Soil Environ. 2006;52:531-43.

Longo RM, Espíndola CR. C-orgânico, N-total e substâncias húmicas sob influência da introdução de pastagens (Brachiaria sp.) em áreas de Cerrado e Floresta Amazônica. R Bras Ci Solo. 2000;24:723-9.

Loss A, Pereira MG, Perin A, Coutinho FS, Anjos LHC. Particulate organic matter in soil under different management systems in the Brazilian Cerrado. Soil Res. 2012;50:685-93.

Machado PLOA. Carbono do solo e a mitigação da mudança climática global. Quím Nova. 2005;28:329-34.

Materechera SA. Influence of agricultural land use and management practices on selected soil properties of a semiarid savanna environment in South Africa. J Arid Environ. 2014;102:98-103.

Mendonça ES, Matos ES. Matéria orgânica do solo: Métodos de análises. Viçosa, MG: Universidade Federal de Viçosa; 2005.

Neue HU, Gaunt JL, Wang ZP, Becker-Heidmann P, Quijano C. Carbon in tropical wetlands. Geoderma. 1997;79:163-85.

Nortcliff S. Standardisation of soil quality attributes. Agric Ecosyst Environ. 2002;88:161-8.

Pant HK, Rechcigl JE, Adjei MB. Carbon sequestration in wetlands: Concept and estimation. Food Agric Environ. 2003;1:308-13.

Pulrolnik K, Barros NF, Silva IR, Novais RF, Brandani CB. Estoques de carbono e nitrogênio em frações lábeis e estáveis da matéria orgânica de solos sob eucalipto, pastagem e cerrado no Vale do Jequitinhonha - MG. R Bras Ci Solo. 2009;33:1125-36.

Ramos DD, Silva EF, Ensinas SC, Souza NH, Potrich DC, Freitas ME, Formagio ASN, Vieira, MC. Stocks of carbon, total nitrogen and humic substances in soil under different cropping systems. Semina: Ci Agron. 2013;34:2219-28.
Ramos MVV. Veredas do Triângulo Mineiro: Solos, água e uso [dissertação]. Lavras: Universidade Federal de Lavras; 2000.

Ribeiro JF, Walter BMT. Fitofisionomias do bioma Cerrado. In: Sano SM, Almeida SP, editores. Cerrado: Ambiente e flora. Planaltina: Empresa Brasileira de Pesquisa Agropecuária; 1998. p.89-166.

Robertson GP, Groffman PM. Nitrogen transformation. In: Paul EA, editor. Soil microbiology, biochemistry and ecology. New York: Springer; 2007. p.341-364.

Roscoe R, Machado PLOA. Fracionamento físico do solo em estudos da matéria orgânica. Dourados: Empresa Brasileira de Pesquisa Agropecuária; 2002.

Salton JC, Mielniczuk J, Bayer C, Fabricio AC, Macedo MCM, Broch DL. Teor e dinâmica do carbono no solo em sistemas de integração lavoura-pecuária. Pesq Agropec Bras. 2011;46:1349-56.

Santos VB, Castilhos DD, Castilhos RMV, Pauletto EA, Gomes AS, Silva DG. Biomassa, atividade microbiana e teores de carbono e nitrogênio totais de um Planossolo sob diferentes sistemas de manejo. R Bras Agroci. 2004;10:333-8.

Statistical Analysis System - SAS. SAS User's guide: statistics. Version 9.1. Cary: Statistical Analysis System Institute; 2003.

Sigua GC, Kang WJ, Coleman SW. Soil profile distribution of phosphorus and other nutrients following wetland conversion to beef cattle pasture. J Environ Qual. 2006;35:2374-82.

Silva IR, Mendonça ES. Matéria orgânica do solo. In: Novais RF, Alvarez V VH, Barros NF, Fontes RLF, Cantarutti RB, Neves JCL, editores. Fertilidade do solo. Viçosa, MG: Sociedade Brasileira de Ciência do Solo; 2007. p.275-374.

Sousa RF, Nascimento JL, Fernandes EP, Leandro WM, Campos AB. Matéria orgânica e textura do solo em veredas conservadas e antropizadas no bioma Cerrado. R Bras Eng Agric Amb. 2011;15:861-6.

Stevenson FJ. Humus chemistry: Genesis, composition, reactions. $2^{\text {nd }}$ ed. New York: John Wiley and Sons; 1994.

Von Lützow M, Kögel-Knabner I, Ekschmitt K, Flessa H, Guggenberger G, Matzner E, Marschner, B. SOM fractionation methods: Relevance to functional pools and to stabilization mechanisms. Soil Biol Biochem. 2007;39:2183-207.

Wantzen KM, Couto EG, Mundc EE, Amorim RSS, Siqueira A, Tielbörger K, Seifan, M. Soil carbon stocks in stream-valley-ecosystems in the Brazilian Cerrado agroscape. Agric Ecosyst Environ. 2012;151:70-9.

Wendling B, Jucksch I, Mendonça ES, Vinhal-Freitas IC. Mudanças no carbono e nitrogênio em diferentes compartimentos da matéria orgânica sob sistema agrossilvipastoril. Ci Flor. 2011;21:641-53. 